\title{
Romance, tempo e história: uma análise comparada de Em liberdade e O ano da morte de Ricardo Reis
}

\begin{abstract}
Antônio Galvão ${ }^{1}$
RESUMO: O presente ensaio traz uma discussão teórica acerca da noção de tempo no romance brasileiro Em liberdade, de Silviano Santiago, e o português $O$ ano da morte de Ricardo Reis, de José Saramago. Ao comparar as duas narrativas de língua portuguesa, objetivamos perceber os modos pelos quais há uma ênfase sobre o tempo presente nos romances, principalmente quando abordados nos diálogos que ambos mantêm com a história.

ABSTRACT: The present essay brings a theoretical discussion about the notion of time in the Brazilian novel Em liberdade, by Silviano Santiago, and the Portuguese $O$ ano da morte de Ricardo Reis, by José Saramago. By comparing these two narratives in Portuguese language, we aim at realizing the ways in which there is an emphasis on the present time in these novels, mainly when they are approached in the dialogues both keep with history.
\end{abstract}

PALAVRAS-CHAVE: Tempo; Romance de Língua Portuguesa; História.

KEY-WORDS: Time; Portuguese Language Novel; History.

Seja qual for o modo de abordar a literatura brasileira, em suas múltiplas manifestações, permanece a impressão de que o estudo de literatura no Brasil perpassa o estudo de literatura comparada. Profundamente marcado pelo cruzamento, sempre híbrido e irregular, de culturas distintas, tais como as de Portugal, dos países africanos de língua portuguesa e, de caráter não menos intrincado, dos diferentes Brasis, o Brasil revela, portanto, literaturas cuja crítica é mais amplamente feita a partir de uma perspectiva comparada.

Assim, comparar as literaturas portuguesa e brasileira significaria perceber as mais variadas relações de parentesco e analogia, sob os mais diferentes aspectos, a partir de aproximações e confrontos entre determinados fatos, históricos ou não, e textos literários, quaisquer as variações de tempo e de

\footnotetext{
${ }^{1}$ Doutorando UFG. E-mail: antoniojoao1 @ gmail.com.
} 
espaço observadas. Isto é, a comparação entre obras literárias do Brasil e de Portugal, de obras de um país e autores de outro, entre autores portugueses e brasileiros, de características dos movimentos literários dos dois países ou ainda o contraste de temas e elementos, recorrentes ou não, entre os países separados pelo Atlântico, porém aproximados por suas literaturas.

Comparar significaria a percepção de variadas relações de parentesco, analogia e, inclusive, de influência. No entanto, o uso do futuro do pretérito não é aleatório. Aqui, ele insinua uma alteração profunda nos pressupostos, objetivos e métodos da literatura comparada. Uma subversão de seus alicerces. Ou ainda uma revisão dos estudos comparatistas de tal modo que seja possível não apenas estabelecer semelhanças e diferenças, mas mudar a ênfase tradicionalmente dada às diferenças e às semelhanças entre os objetos literários tomados em comparação. Essa proposta de mudança nos modos dos estudos comparados em literatura, adotada neste artigo, tem em Perrone-Moisés (1990) suas bases teóricas.

Revisões, subversões, alterações. Difícil seria conceber o século XX sem suas intensas mudanças, nos mais diferentes ramos da atuação humana. Desse modo, a relação de sinonímia entre as palavras "revisão", "subversão" e “alteração" é uma das maneiras de tentar descrever esse breve século, por vezes marcado pelo estigma do extremo e do catastrófico. Se alteradas as rotas das atividades de homens e mulheres; se a tradição, sempre canônica e dogmática, é subvertida; e se a história é finalmente revista, então é possível compreender os movimentos de mudança no conceito de literatura comparada como consequência de algo ainda maior: os modos outros como se concebe a obra literária.

Ora, não é mais plausível aceitar o texto literário em uma suposta imobilidade opaca, cega e condicionada. Ao contrário, a obra literária deve ser considerada em toda sua fluidez. Disso decorre uma atitude crítica diferenciada diante da literatura e, por conseguinte, dos estudos comparados. Já que o texto literário está impregnado de múltiplas marcas acerca de seus processos de formação e tomado por diálogos e transformações, são outras as atitudes da 
literatura comparada ao "... privilegiar a busca das diferenças sobre a das analogias, o estudo das transformações sobre o dos parentescos, a análise das absorções e integrações como uma superação das influências" (Perrone-Moisés, 1990, p. 96).

Diferenças, transformações e absorções. Diante da irreversível ação do tempo, mudam também os cursos da ação humana, mudam as relações entre as literaturas do Brasil e de Portugal, mudam as noções do que é alheio e do que é próprio. Emergem, agora, uma pluralidade de diálogos e trocas entre obras e autores portugueses e brasileiros, de tal modo que a discussão, outrora pertinente, sobre originalidade e verdade torna-se irrisória, senão pífia. A tradição, antes estável, está em permanente mutação; subvertida, ela se transubstancia em outra, já não mais influi, passa a convergir. E de tal modo se imiscuem diálogos, trocas e convergências, que a atitude diante do autor outro e da obra outra, quaisquer as literaturas em língua portuguesa, igualmente mudam: deseja-se esse outro, abre-se diante desse outro e devora-se, criticamente, o outro. Tal é o terreno, irregular e híbrido, sobre o qual compararemos o romance brasileiro Em liberdade, de Silviano Santiago e o português $O$ ano da morte de Ricardo Reis, de José Saramago, publicados, respectivamente, em 1981 e em 1984, com o objetivo de analisar os modos pelos quais a ênfase, nessas narrativas, recai sobre o tempo vivido².

1984, 1981, 1936. Tanto para a história quanto para a literatura existe a data. E, dentre as inúmeras relações que a literatura mantém com a história, há aquela entre o fato histórico, real ou imaginado, registrado, seja pela escrita ou pelas oralidades, em uma data qualquer, e as muitas vias de ficcionalização desse fato ou do que há ao seu redor. Assim, o fato coloca-se entre a história, a ficção e a literatura, ramos distintos cujo tronco comum constitui-se na

2 Parte da bibliografia aqui utilizada e a sugestão de análise dos romances de José Saramago e de Silviano Santiago são indicações do Prof. Dr. Edvaldo Bérgamo (UnB), a quem agradeço. Tive acesso aos textos teóricos durante o curso de pós-graduação stricto sensu "Literatura, história e autoritarismo: o romance de ênfase social de língua portuguesa". 
linguagem e na imaginação humana. No entanto, apesar da tradicional distinção epistemológica entre literatura, ficção e história, é possível visualizar uma aproximação entre as três, já que "O caráter de ciência, conquistado pelo conhecimento histórico, não suprime a base narrativa, que mantém o seu nexo com o ficcional" (NUNES, 1988, p. 12). E esse contato é possível em função do teor temporal da narrativa, definido por Paul Ricoeur (1997) em Tempo e narrativa, sobre o que discorreremos adiante.

1936. Ano crucial para Brasil, Portugal e Europa. À presidência da república brasileira, Getúlio Vargas engendra o repressor Estado Novo (19371945), responsável, entre outros exercícios arbitrários de poder, por perseguição política e ideológica aos opositores do regime, supressão de direitos civis, censura indiscriminada. Do outro lado do Atlântico, percebem-se também atitudes autoritárias semelhantes. Sob o governo ditatorial de António Salazar (1932-1968), em Portugal, eclodem políticas de tortura e de extermínio premeditado. De alguns outros países europeus, emerge a sinistra sombra dos regimes totalitaristas, cujo remate será a Segunda Guerra Mundial (1939-1945).

Voltemos ao Brasil e a Portugal. Devido a divergências administrativas locais e às posições políticas à esquerda daquela da ditadura de Vargas, o escritor alagoano Graciliano Ramos é preso e mantido no cárcere por dez meses e dez dias, saindo da prisão apenas em 1937. Tal é o enredo, aliás, do romance Em liberdade, o qual problematiza as tensões entre verdade e ficção ao reconstituir os dias de Ramos após sua saída da cadeia, aí a história, e a escrita de um diário, aí a ficção. Ou seja, 1936 é o ano da prisão, da supressão da liberdade, da morte em vida, de Graciliano Ramos. Igualmente, 1936 é O ano da morte de Ricardo Reis, aqui tomado tanto como título do romance de José Saramago (1988) e, ainda, como fato, historicamente falso, ficcionalmente verdadeiro. É o ano no qual o médico e poeta Ricardo Reis, depois de dezesseis anos passados no Rio de Janeiro, decide retornar a Lisboa, ao saber do falecimento de Fernando Pessoa, seu criador e amigo.

Falso para a história e, no entanto, verdadeiro para a ficção. É a partir dessa relação, sempre sinuosa e instigante, entre a literatura e a história que 
emergem algumas perguntas: onde se situam as representações da vida e do real quando colocadas entre a ficção e a história? Quem são e de quais formas são possíveis Salazar, Fernando Pessoa, Ricardo Reis, Graciliano Ramos e Vargas, em seus variados espaços e na multiplicidade de tempos de onde enunciam suas verdades esses personagens, reais agora fictícios, fictícios tornados reais? Ou ainda, o que é realidade e o que é ficção, confrontados o discurso histórico e a narrativa literária, comparados os romances $O$ ano da morte de Ricardo Reis e Em liberdade?

"A obra do poeta não consiste em contar o que aconteceu, mas sim coisas quais poderiam acontecer, possíveis no ponto de vista da verossimilhança ou da necessidade". (ARISTÓTELES, 1997, p. 28, grifo nosso) Essa é a clássica distinção aristotélica entre a criação literária, discurso do que poderia ter acontecido, e a história, narrativa do que aconteceu, tal como se assenta a sua pretensão. Em outras palavras, a ficção, enquanto um poderia ter sido, é um ato de fingir, de simular, de imaginar, o que afronta sobremaneira as bases epistemológicas da história, tida como narrativa organizada de fatos acontecidos. Assinala essa elaboração do fato passado, dado como verídico, uma vontade de verdade, esse o empenho do historiador e, por isso mesmo, sua incansável pretensão, pois ao tentar alcançar as verdades possíveis de uma realidade acontecida, a história gostaria de atingir o inatingível, a experiência do vivido. E esse esforço pelo inalcançável sustenta-se sobre marcas de historicidade presentes em fontes, evidências do fato ocorrido no passado. Atado como está à fonte, o historiador precisa escrever versões plausíveis do que ocorreu um dia, chegando, portanto, à

[...] verossimilhança, não à veracidade. Ora, o verossímil não é a verdade, mas algo que com ela se aparenta. O verossímil é o provável, o que poderia ter sido e que é tomado como tal. Passível de aceitação, portanto. Registramos, com isto, a mudança deliberada do tempo verbal: o poderia, o teria sido, com o que a narrativa histórica, representação do passado, aproximar-se-ia, perigosamente, da definição aristotélica da 
poesia, pertencente ao campo da ficção. Ou seja, as versões do acontecido são, de forma incontornável, um poderia ter sido (PESAVENTO, 2006, p. 16, grifo do autor).

Graciliano Ramos foi preso em 1936. Quando Em liberdade, em 1937, ele poderia ter escrito um diário, no qual discorreria sobre a sociedade carioca, a literatura própria e a alheia, as graves circunstâncias políticas do passado e do presente brasileiro. Nada mais verossímil, logo aceitável, ao considerarmos sua postura intelectual crítica. Ficção no interior da ficção, $O$ ano da morte de Ricardo Reis é o de 1936. Solidifica-se o governo de Salazar, cujo alcance, tal qual uma estátua cinza e ameaçadora multiplicada pela cidade de Lisboa, cerceia, à espreita, os passos, já não mais plácidos, de Ricardo Reis. Dali a três anos, as frias noites na Europa testemunhariam o horror dos genocídios, das bombas e do sangue humano. Nada mais plausível, verossímil, portanto, considerado o alheamento cultivado pelo poeta e médico, que a sua opção, em companhia de Fernando Pessoa, seja pela partida e abandono do mundo em chamas.

Assim, é pela verossimilhança dessas narrativas, é pela plausibilidade dessas verdades, reais ou imaginárias, é, enfim, pelo análogo teor do teria acontecido, que se aproximam a literatura e a história. Afinal, embora o escritor de literatura não tenha o compromisso do historiador com marcas de historicidade na narrativa, cara à história, é inegável que, para certo tipo de literatura, aquela de caráter mais próximo das representações da realidade, e esse é o caso dos romances históricos de José Saramago e de Silviano Santiago aqui estudados, o texto literário deve ser verossímil, característica percebida em um enredo cujas articulações internas sejam coerentes. No centro dessa articulação está a personagem. Residem, inquietos, Graciliano Ramos e Ricardo Reis, movem-se Heloísa e Lídia, contrastam profundamente José Lins do Rego e Fernando Pessoa. Personagens imprevisíveis e fluidas, uma das marcas, aliás, do romance enquanto gênero, cujas ações, muitas vezes demasiadamente erradas, porque humanas, engendram o enredo. Historicamente, o que teria sido 
em 1936 tanto para Graciliano quanto para Reis, o foi na literatura, na verdade da ficção.

Comparados, portanto, os romances nos quais Ricardo Reis falece e Graciliano Ramos sai do cárcere, contrastadas a ficção e a história, chegamos a uma postura diferenciada, a um terreno outro, “... onde o mar se acabou e a terra espera" (SARAMAGO, 1988, p. 415): ao da diluição de fronteiras nítidas entre a história e a literatura. Ao terreno híbrido onde realidade e não-realidade - a Rua Alfredo Chaves, no Rio de Janeiro, em 1937; o Hotel Bragança, em Lisboa, em 1936 -, as verdades ocultas e as ficções aparentes da representação, reveladas pela narrativa literária estão, afinal, em ininterrupto cruzamento. Eis uma das mais relevantes características que assume o gênero romance no século XX.

Já havíamos discorrido brevemente sobre o século XX e apontado, tal como lemos nos romances $O$ ano da morte de Ricardo Reis e Em liberdade, os rastros escusos da intolerância, do autoritarismo e da violência, atitudes arbitrárias dos governos ditatoriais de António Salazar e de Getúlio Vargas. Em uma compreensão mais ampla, tais procedimentos resultam da diferença entre orientações políticas, como é o caso das ditaduras militares de direita, na América Latina, e da sistemática perseguição aos esquerdistas na Europa, atestada pela Guerra Civil Espanhola, por exemplo. Raras não são as convergências da violência e do autoritarismo políticos, enquanto tema e forma, na literatura concebida no catastrófico século $X X$, quaisquer as línguas, quaisquer os gêneros literários.

No entanto, e como continuidade da discussão anteriormente apresentada acerca das sinuosas relações entre história e literatura, é preciso ressaltar a distinção da literatura sobre as circunstâncias sociais, materiais e históricas que, eventualmente, sobre ela incidam ou a ela se refiram. Ou seja, para além de conceber a obra literária como totalmente condicionada a fatores materiais e econômicos externos a ela, o que a reduziria a mero documento ou mesmo a panfleto, deve-se perceber na obra as articulações e movimentos 
internos, sempre complexos, entre as conjunturas históricas e as formas literárias que emergem no texto quando do trato com os tais quadros providos pela história. Por isso, o valor da literatura está precisamente nas marcas profundas que ela causa na linguagem. Estabelecidas essas considerações, discutamos, sucintamente, o romance do século XX para perceber suas formas, peculiaridades e traços.

“O romance é o único gênero por se constituir e ainda inacabado. [Não obstante], não podemos prever todas as suas possibilidades plásticas" (BAKHTIN, 1990, p. 397). É precisamente esse caráter inconcluso e maleável do romance, cujas formas ainda são imprevisíveis, fragmentadas e em constante formação, que o localiza no âmbito das mudanças operadas pela arte literária no século XX. E tal é o alcance das profundas particularidades estruturais do gênero romance que seria impossível discorrer sobre todas elas neste ensaio. Por isso, discutamos apenas uma dessas características: o contraste entre o romance e a epopeia enquanto formas que estruturam a representação literária do tempo de modo completamente distinto. Aliás, é em decorrência dessa divergência fundamental entre os dois gêneros e das características intrínsecas aos romances Em liberdade e $O$ ano da morte de Ricardo Reis, no tocante às configurações do tempo no romance, que aqui discutimos como se estrutura a ênfase sobre o tempo vivido, comparadas as narrativas de Santiago e de Saramago. O tempo vivido é o tempo do presente, ainda que esse presente desdobre-se em temporalidades outras, como o detecta, aliás, Santo Agostinho (1996) no Livro XI de suas Confissões. E é o romance o gênero a assimilar esse presente inacabado e multiplicado na figuração da imagem literária, diferentemente da epopeia, aquela cujo passado é absoluto e distante, cujos moldes rígidos e acabados, harmônicos e plenos, desnudam, na verdade, “[...] o caráter exaustivo dessa poética" (BAKHTIN, p. 398). Por isso, a desagregação da epopeia. Por isso, Ricardo Reis não consegue concluir a leitura de The God of the labyrinth. Esse deus épico e pleno já não existe mais. A partir de 1936, as Odes já não mais serão compostas. É tempo de escrever as Memórias do Cárcere. O que resta, portanto, é o romance. Em liberdade. 
Liberdade experimentada no Rio de Janeiro, em 1937. Agora, o ex-preso político Graciliano Ramos reflete, em seu diário, sobre as tortuosas relações entre a intransigência do Estado e o papel do intelectual, as divergências políticas e literárias entre ele e José Lins do Rego, as diferenças da vida em Maceió e no Rio de Janeiro. No mesmo ano, Ricardo Reis já não estaria em Lisboa, pois sua partida se dera em 1936, ano no qual o poeta não conseguiu compor suas odes, foi cerceado e interrogado pela polícia política de Salazar, imiscuiu-se aos pobres durante o bodo do Século, ainda que à distância, da Calçada dos Caetanos, porque "[...] dali podia apreciar o ajuntamento quase à vol d'oiseau" (SARAMAGO, 1988, p. 70). Se há uma forma de substantivar o percurso de ações das personagens nesses romances é pelo conflito e pela contradição. O conflito entre as causas individuais do poeta e do romancista contra as do Estado. A contradição entre o cárcere e a liberdade, o mundo e o espetáculo.

Ora, "É no romance, ademais, que as contradições específicas da sociedade burguesa têm sido figuradas do modo mais adequado e mais típico" (LUKÁCS, 1992, p. 177) e, de tal modo, que toda uma reverberação dessas contradições, históricas, repercute e age sobre as formas literárias do romance. Vejamos. Em primeiro lugar, onde a sociedade do século XX é paradoxal e fragmentada, o romance exibe-se igualmente contraditório e inacabado, portador de múltiplas vozes, e nisso sua distinção artística, pois figura e refaz, pela linguagem literária, o grave teor do mundo. Em segundo, a análise aproximada empreendida no romance e que se concentra na ação individual do homem revela, tal qual uma lupa que se detém sobre o detalhe mínimo, o horror e a degradação humana, o herói às avessas, vide os autoritarismos, as guerras, as ditaduras, sobre o que já discorremos. E, em terceiro lugar, a barbárie penetra na forma do romance de ênfase social ao trazer

[...] uma nova contribuição do realismo autêntico, tentativas vigorosas e frequentemente bem sucedidas para superar, na figuração literária, as influências da decadência (Naturalismo e 
tendências abertamente antirrealistas). Exclusivamente através desta luta violenta entre o humanismo e a barbárie, entre o realismo e a fuga à realidade, o escapismo, torna-se possível determinar, em seus traços essenciais, a característica do romance burguês contemporâneo (LUKÁCS, 1992, p. 186, grifo nosso).

Narrativas fragmentadas, multiplicidade de perspectivas e de vozes no interior da obra, o herói contraditório e incerto e, no entanto, ainda a realidade como referente. Ainda os retratos e os quadros, embora disformes, do mundo. Ainda a persistência de um realismo na figuração literária, como o nota Lukács (1992), a despeito de todas as subversões e alterações por que passa a forma do romance no século XX. "Escrever poesia após Auschwitz é um ato de barbárie", diria Adorno. É assim, entre os escombros da forma e a barbárie do mundo, que percebemos o desconforto que a obra literária enfrentaria se ignorasse o horror do autoritarismo e da violência ditatoriais no Brasil e em Portugal. Por isso, o realismo e a realidade no romance de ênfase social do século XX. Tratam do realismo, sem dúvida, Em liberdade e $O$ ano da morte de Ricardo Reis. Mas tratam de um outro realismo. Antes, as representações do real nesses romances tomam-no como mero referente, simples ponto de partida, para outra localidade mais ampla e profunda, onde "[...] o mar acaba e a terra principia" (SARAMAGO, 1988, p. 11): as deformações da realidade engendradas no texto literário.

Tais mudanças intensas nas camadas de realidade que penetram o romance contemporâneo mantêm um diálogo com a história. Uma história, porém, à beira da falésia, feita de restos e indícios, vista de baixo (CHARTIER, 2002; GINZBURG, 2002; SHARPE, 1992). É essa perspectiva de rebaixar a História maiúscula a uma história mais ampla, associada à realidade enquanto referente privilegiado, que caracteriza, em linhas gerais, o solo teórico a sustentar-nos na comparação entre $O$ ano da morte de Ricardo Reis e Em liberdade: o da metaficção historiográfica, definida como uma refutação dos 
[...] métodos naturais, ou o senso comum, para distinguir entre o fato histórico e a ficção. Ela recusa a visão de que apenas a história tem uma pretensão à verdade, por meio do questionamento da base dessa pretensão na historiografia e por meio da afirmação de que tanto a história quanto a ficção são discursos, construtos humanos, sistemas de significação, e é a partir dessa identidade que as duas obtêm sua pretensão à verdade (HUTCHEON, 1991, p. 127).

Assim, ao problematizar, no texto, as contradições entre a referência histórica e a autorreferência ficcional, e em consonância com os pressupostos novos da literatura comparada expostos anteriormente, a metaficção historiográfica promove: a) apropriações intertextuais reforçadoras de temáticas do texto outro; b) posturas irônicas e sarcásticas às pretensões de legitimidade do texto primeiro, o que causa o desconcerto e a desestabilização, típicos da paródia e do pastiche; c) ficcionalizações de personagens históricos, geralmente para refutá-los; d) uma autorreflexão constante sobre os percursos de escrita da narrativa; e) encenações fictícias do cânone literário para corromper e adaptar seu sentido primeiro; f) a polifonia, marcada pela multiplicidade de discursos e vozes; g) questionamentos acerca da vontade de verdade da história.

Traços da metaficção historiográfica repercutem a todo instante nos romances de Silviano Santiago (1994) e de José Saramago (1988). Sentidos outros são recuperados e criados sobre Graciliano Ramos e Ricardo Reis, José Lins do Rego e Fernando Pessoa. Em um, o escritor alagoano tem uma ereção na praia carioca. No outro, a eminência de Luís de Camões petrificou-se, pois sua memória é evocada por uma estátua em uma praça qualquer em Lisboa. Enquanto personagem, Ramos questiona a verdade da história ao percorrer arquivos para investigar as causas do suicídio de Cláudio Manuel da Costa. Já em Saramago, o cruzamento das muitas vozes, de diferentes personagens, em longos parágrafos, é marcado por diferentes temporalidades, como em encaixe. Em liberdade, emergem os vultos do inconfidente Cláudio Manuel da Costa, no 
século XVIII, e do jornalista Wladimir Herzog, em 1975, durante a ditadura militar no Brasil. Em O ano da morte de Ricardo Reis, 1936, o poeta helenista Ricardo Reis ainda conversa com Fernando Pessoa, cuja morte ocorrera em 1935, década sombria que testemunharia, quatro anos depois, a eclosão da Segunda Guerra Mundial.

1789, 1936, 1968. Abafam-se as Inconfidências, morre o poeta monárquico, prendem o romancista nordestino, camufla-se o suicídio dos resistentes nos porões escuros das ditaduras militares. Decorrem dias, meses e anos e, no entanto, persiste o tempo. Resiste, ainda que irreversível, o tempo, seja pela lembrança, pela memória ou pela impossibilidade do esquecimento. É na literatura, ademais, que o tempo da experiência humana assume as mais variadas figurações. E ao adentrar no romance, gênero inacabado, ainda por constituir-se, sempre múltiplo, já o dissemos, as possibilidades artísticas de figuração do tempo na narrativa são infinitas. Nisso a particularidade do estudo do romance e a dificuldade em estabelecer modelos a servir de parâmetro a outros romances. No entanto, a despeito da complexidade inerente às relações entre o tempo e a narrativa, é ele o elemento a estruturar, tal qual arquiteto, o enredo em seus contatos profundos com as categorias do narrador, do espaço e da personagem, como o percebemos nos romances Em liberdade e $\mathrm{O}$ ano da morte de Ricardo Reis.

\section{A natureza temporal da narrativa}

Tema central em suas pesquisas em teoria da história e da narrativa, Paul Ricoeur (1986) estabelece da seguinte forma as reciprocidades entre narrativa e tempo: “Tudo o que se conta acontece no tempo, toma tempo, desenvolve-se temporalmente, e o que se desenvolve no tempo pode ser contado. Talvez mesmo todo processo temporal só seja reconhecido como tal na medida em que pode ser narrado de certa forma" (RICOEUR, 1986 apud NUNES, 1988, p. 15, grifo nosso). Isto é, a ação que se desenvolve no tempo pode ser narrada, 
quaisquer as modalidades de narrador. Tal fato é justamente considerado temporal, compreendido em uma totalidade provida pelo tempo, porque sua compreensão é possível através do contar que se elabora na narrativa literária. Então vejamos, de modo sucinto, um percurso teórico imprescindível à compreensão da natureza temporal da narrativa literária e, consequentemente, do romance.

Já havíamos reiterado o caráter de recriação, transposição e reconfiguração da realidade que marca a literatura. Nisso reside seu teor literário e valor artístico, na medida em que problematiza e transporta os níveis ordinários de apreensão da realidade para linguagens outras, como a da metáfora, por exemplo. A metáfora, enquanto transferência de sentido do nome para o plano de predicação, é um dos modos privilegiados para superar o nível de superfície da linguagem. Assim, sua impertinência e astúcia permitem acessos a outras referências, ocultas e profundas talvez, sobre o sentido primeiro, o literal. Essa sobreposição do sentido literal para o sentido metafórico arquiteta-se, no texto literário, em decorrência da mímesis, ou seja, a imitação ou transfusão poética da realidade. Por sua vez, essa realidade, enquanto referente, transpõe-se poeticamente para a obra por meio do enredo, $\mathrm{o}$ qual, organizado como está em um sistema, é então abrangido em uma só forma: a narrativa (NUNES, 1988).

Assim, o enredo de uma narrativa deve ser organizado e inteligível, já que participa da transfusão poética da realidade. Consequentemente, o enredo é uma operação de configuração, pois: a) reúne diversos fatos dispersos no conjunto de uma história; b) liga uma multiplicidade de fatos e episódios em uma só totalidade; c) sintetiza a singularidade de um fato isolado com a amplitude da história como um todo. É, portanto, a partir dessa última característica que emerge a natureza temporal da narrativa. Dessa constatação resultam, por último, as duas dimensões do tempo na narrativa: a dimensão episódica e a do todo. A primeira é cronológica, refere-se à sucessão de fatos e acontecimentos históricos, possui começo, meio e fim. Já a segunda, não cronológica, permite vislumbrar a unidade de uma história: ao concatenar o 
começo ao fim e esse ao começo, ela abrange a amplitude de um tema e permite uma síntese que preenche as lacunas da narração. Marca, ainda, a dualidade temporal da narrativa, a distinção entre o tempo do fato narrado e um outro, o tempo do narrar aquele fato. Essa dualidade pode ser constantemente cortada por idas e vindas, prospectos e retrospectos, nas muitas temporalidades da narração. São esses procedimentos, organizados pelo enredo, que conduzem à compreensão geral da narrativa da ação do homem (RICOEUR, 1986 apud NUNES, 1988).

No entanto, os tempos da alma humana são muitos, sempre insondáveis, "Vós acendereis a minha candeia, Senhor Meu Deus, e iluminareis as minhas trevas" (SANTO AGOSTINHO, 1996, p. 333). Assim se posiciona Santo Agostinho (1996) quando constata pela extensão, ou distensão, da alma humana a possibilidade de medir-se o tempo:

Acaso minha alma não Vos engrandece ao declarar-Vos, com verdade, que meço os tempos? Efetivamente, meu Deus, eu meço-os, e não sei o que meço [...]. Pelo que, pareceu-me que o tempo não é outra coisa senão distensão; mas de que coisa o seja, ignoro-o. Seria para admirar que não fosse a da própria alma. Portanto, dizei-me, eu Vo-lo suplico, meu Deus, que coisa meço eu, quando declaro indeterminadamente: "Este tempo é mais longo do que aquele", ou quando digo determinadamente: "Este é duplo daquele outro?" Sei perfeitamente que meço o tempo, mas não o futuro porque ainda não existe. Também não avalio o presente, pois não tem extensão, nem o passado, que não existe. Que meço eu então? O tempo que presentemente decorre e não o que já passou? Assim o tinha dito eu (SANTO AGOSTINHO, 1996, p. 334, grifos do autor).

O passado, o que deixou de ser, o presente, o que passa, e o futuro, o que ainda não existe, somente poderiam ser abrangidos pela extensão da alma. 
Assim, a alma humana alcançaria o passado pela memória, o presente pela atenção e o futuro pela expectativa. No entanto, ao notar a incerteza em se afirmar a existência de três tempos, Santo Agostinho (1996) sugere a junção dos três em um só momento, o presente triplicado: o presente do passado, o presente do presente e o presente do futuro. Desse modo, a alma humana concentrar-se-ia naquele presente do presente, “[...] por onde o tempo passa e pelo qual pode ser medido, de modo que o futuro vai se tornado passado na medida em que se abrevia a expectativa e alonga-se a memória" (NUNES, 1988, p. 18).

Passado, presente ou futuro, é a voz narrativa que conta o enredo, transposto poeticamente da realidade, em volta de uma personagem em um espaço qualquer. Retornamos, mais uma vez, a Ricoeur (1986): “[...] todo processo temporal só [é] reconhecido como tal na medida em que pode ser narrado de certa forma" (RICOEUR, 1986 apud NUNES, 1988, p. 15). Compreendamos, enfim, a partir de Paul Ricoeur (1997) e de Santo Agostinho (1996), os amálgamas entre narração, espaço, personagem e a natureza temporal da narrativa nos romances $O$ ano da morte de Ricardo Reis e Em liberdade.

\section{Narração, tempo e romance}

Apropriando-nos da constatação de Ricoeur (1986) para relacioná-la aos romances de Silviano Santiago (1994) e de José Saramago (1988), diríamos ser a natureza temporal desses romances que permite a existência de uma voz narrativa em ambos. A compreensão temporal da vida de Graciliano Ramos e de Ricardo Reis, de seus percursos incertos pelas ruas do Rio de Janeiro e de Lisboa e de seus relacionamentos amistosos ou não, públicos ou íntimos, é possível porque contada por um narrador. É essa voz narrativa, portanto, que vincula as verdades ficcionais imbuídas no interior dessas obras aos indícios de realidade histórica presentes em cada um dos romances.

Assim, vejamos como os procedimentos da voz narrativa em $O$ ano $d a$ morte de Ricardo Reis e Em liberdade relacionam-se à dualidade temporal da 
narração. Narrado em primeira pessoa, o romance de Santiago (1994) opera uma coincidência entre a personagem principal do enredo, o escritor alagoano Graciliano Ramos, e a posse, por ele tomada, da principal voz narrativa no romance. Isto é, personagem e narrador principais são, a priori, os mesmos. As características da dualidade temporal dessa narração, a ocorrência de prospectos e retrospectos ao longo da narrativa, são percebidas a partir da escrita de um diário por Ramos, no qual ele discorre sobre a experiência de seu tempo vivido:

$1^{\mathrm{o}}$ de fevereiro (segunda-feira). Existe alguma lógica na escolha dos sucessivos assuntos de que trato neste diário? Possuo eu esta lógica? Ou seja: sou quem organiza os temas? Ou está ela sendo dada de presente, como eu acreditei, pelo acaso? [...] Dou-me conta - verdade bem acaciana - de que não posso escrever neste bloco tudo o que acontece, mesmo se qualifico o que acontece de importante. [...] Quando consigo a solidão no quarto e me proponho a narrar o acontecido, vejo que a bolha de sabão explodiu no ar. [...] Tudo o que aconteceu na primeira semana está sendo esquecido, ou foi esquecido, com uma rapidez impressionante. Por sorte, escrevi este diário (SANTIAGO, 1994, 132-133).

É a data que caracteriza este tipo de texto, escrita diária de circunstâncias da vida de uma pessoa. À data, soma-se o registro do lugar onde se encontra Graciliano Ramos, “1937/ Rio de Janeiro/ Residência do romancista José Lins do Rego/ Rua Alfredo Chaves - Largo dos Leões" (SANTIAGO, 1994, p. 20). Logo, é a partir da localização provida pela data e lugar que se projeta o narrador. Além disso, a data e o lugar produzem um efeito de verossimilhança na narrativa já que esta, contada em primeira pessoa, poderia induzir à dúvida e à incerteza, pois as narrativas do "eu" usam apresentar uma visão parcial do mundo, aquela de quem a narra. À superfície a partir da data, essa voz narrativa alcança prospectos e retrospectos não muito distantes daqueles do 
tempo do narrar: "Sábado e domingo foram dias movimentados e cheios" (1994, p. 54, grifo nosso), escrito na segunda-feira, pela manhã; "Pouco saio de casa à noite. Aproveito para ler ou escrever" (1994, p. 104, grifo nosso); “Diante do que (não) faço no Rio de Janeiro para sobreviver, não deixa de ser interessante ir a São Paulo [...]" (1994, p. 207, grifo nosso). Passado, presente e futuro, marcados pelos verbos "foram", "saio" e "ir", aproximam o tempo do narrado ao tempo do narrar.

Tal postura narrativa, o alcance reduzido de recuos e projeções temporais, traz o leitor de Em liberdade para o nível do enunciado pelo enredo. Consequentemente, leitor e Graciliano Ramos tornam-se próximos, do mesmo modo como também se tocam leitor e Cláudio Manuel da Costa, cuja narrativa é amalgamada ao diário de Graciliano de tal modo que, a partir de certo momento, já não é mais possível distinguir entre o diário de Ramos, a narrativa de Cláudio, a ficção de Santiago (1994), instâncias confluídas e muito próximas do leitor pela ênfase sobre o presente da narração. Ora, uma hipótese para compreender essa proximidade narrativa é o ano de 1981, ano de publicação de Em liberdade. Presente, a memória do assassinato de Wladimir Herzog, seis anos antes, ainda repercute entre a sociedade brasileira. A sombra do autoritarismo permanece próxima demais. É preciso trazer, para o interior da narrativa, marcada pelo tempo presente, essa proximidade assustadora com o horror, o qual está aqui, ao lado do leitor, de Graciliano, Heloísa, Cláudio, Wladimir, Santiago, Ricardo, Lídia, José, da história humana, enfim.

Não é o poeta helenista e de formação clássica quem narra, em $O$ ano da morte de Ricardo Reis, o decurso de suas ações em Portugal. Diferente, a voz narrativa em Saramago (1988) é preferencialmente em terceira pessoa. Ela atravessa o romance em múltiplas dimensões do tempo, liga espaços e temporalidades muito distantes, promove retrospectos e avanços temporais variados, como se fosse uma narrativa labiríntica, tal são os encaixes e desdobramentos concebidos pelo narrador: 
E há papéis para guardar, estas folhas escritas com versos, datada a mais antiga de doze de Junho de mil novecentos e catorze, vinha aí a guerra, a Grande, como depois passaram a chamar-lhe enquanto não faziam outra maior, Mestre são plácidas todas as horas que nós perdemos, se no perdê-las, qual numa jarra, nós pomos flores e seguindo concluía, Da vida iremos tranqüilos, tendo nem o remorso de ter vivido. Não é assim, de enfiada que estão escritos, cada linha leva seu verso obediente, mas desta maneira, contínuos, eles e nós, sem outra pausa que a da respiração e do canto, é que os lemos, e a folha mais recente de todas tem a data de treze de Novembro de mil novecentos e trinta e cinco, passou mês e meio de tê-la escrito, ainda folha de pouco tempo, e diz, Vivem em nós inúmeros, se penso ou sinto, ignoro quem é que pensa ou sente, sou somente o lugar onde se pensa e sente e, não acabando aqui, é como se acabasse, uma vez que para além de pensar e sentir não há mais nada (SARAMAGO, 1988, p. 23-24, grifo nosso).

É o narrador quem observa os papéis com versos, nos quais lê a data de 12 de junho de 1914, e daí passa a flagrar a Primeira Guerra Mundial (19141918), apenas em relance para, em seguida, imiscuir profundamente sua voz à voz do eu lírico do poeta das Odes. Retoma a observação minuciosa e atenta da folha de papel com os versos. Mesmo sem virá-las, conhece todas as páginas e sabe que a mais recente tem a data de 13 de novembro de 1935. Há pouco tempo, portanto, do tempo do narrar, o ano de 1936, O ano da morte de Ricardo Reis. Disso decorre a sutil ironia do narrador, revelada, no longo parágrafo de Saramago (1988), justamente pela junção de vozes diferentes, pelo contraste brusco entre seu olhar aguçado e os versos das Odes, ainda que cruze o parágrafo os dias 12 e 13, os meses de junho e novembro, os anos de 1914 e 1935. São esses "excessos do narrador" (BAKHTIN, 1990) que preenchem continuamente as lacunas dessa narrativa, de tal modo que é possível perceber o que as personagens não sabem, não veem, não ouvem. Logo, a aparente 
distância que uma narração em terceira pessoa poderia sugerir tem, em Saramago (1988), uma consequência oposta: é essa penetração da voz narrativa nas várias camadas do tempo que, ao unir espaços e temporalidades distantes, aproxima o leitor do fato narrado, levando-o, pela recorrência ao tempo presente - "Sou somente o lugar onde se pensa e sente" (1988, p. 24) - ao interior das verdades da ficção. É impossível distanciar-se após Auschwitz. Por isso, a ênfase sobre o presente tanto Em liberdade quanto em $O$ ano da morte de Ricardo Reis.

\section{Espaço, tempo e romance}

Ainda que Ricardo Reis queira unicamente ter com os deuses, "Que serão os meus sonhos/ Mais que a obra dos deuses?" (REIS, 2006, p. 61), é no ano de sua morte, 1936, que ele se sentiu, de fato, humano e frágil. Graciliano Ramos, ao contrário, torna explícitas suas dúvidas e incertezas: "Não sinto o meu corpo. Não quero sentir meu corpo agora, porque é pura fonte de sofrimento" (SANTIAGO, 1994, p. 25). Aproximados, portanto, por suas aflições, sobressai o teor de humanidade tanto em um quanto no outro. Como suportar o mundo, agora não mais o espetáculo, quando o tempo de Ramos e de Reis não é apenas o ano de 1936, a prisão de um, a morte do outro? Onde se localizam os sonhos de deuses do poeta português e o sofrimento do romancista alagoano?

“É impróprio afirmar que os tempos são três: pretérito, presente e futuro. Mas talvez fosse próprio dizer que os tempos são três: presente das coisas passadas, presente das presentes, presente das futuras" (SANTO AGOSTINHO, 1996, p. 327-328). Assim voltamos à ênfase sobre o presente da ação humana, medido pela extensão da alma, conforme exposto anteriormente. O tempo como função da vivência intencional. Este presente é, no entanto, um presente triplicado, o que aponta para temporalidades outras e nisso uma convergência com o aspecto inacabado e multiplicado do tempo presente no gênero romance (BAKHTIN, 1990). 
Ricardo Reis opta pela partida, pelo abandono do mundo, pois "Não lhe posso valer" (SARAMAGO, 1988, p. 415). E, mesmo em vida, suas ações não eram providas de extensão, distentio, distensão, tormenta. "Mestre, são plácidas/ Todas as horas/ Que nós perdemos/ Se no perdê-las/ Qual numa jarra/ Nós pomos flores" (REIS, 2006, p. 31). Sem extensão, o tempo se espacializa, recairia em um dado espaço, como que se fixasse (NUNES, 1988). Assim, é sobre esse tempo espacializado, um tempo amplo porque se enraizou, ainda que fragilmente, sobre um espaço, que se coloca a narrativa de Saramago (1988) acerca de Ricardo Reis. Dessa constatação, decorrem duas consequências: a) a relevância do espaço, derivado do tempo, em Saramago (1988) e b) os múltiplos desdobramentos narrativos, sobre o que já discorremos, resultado do tempo tornado espaço.

Circunscrevemos, enfim, a discussão teórica sobre narração, personagem e espaço, cortados pelo tempo. Ricardo Reis, o contemplador do momento, para quem “O tempo não passa/ Não nos diz nada” (REIS, 2006, p. 32), anula os atos da extensão humana, os quais gerariam a memória, a atenção e a expectativa. Ricardo Reis não os quer: "Deixo o mundo aliviado de um enigma" (SARAMAGO, 1988, p. 415). Essa opção pela nulidade, o não envolvimento, interrompe nele a extensão do tempo. Logo, o tempo se espacializa no presente. Por isso, a relevância da voz narrativa em $O$ ano da morte de Ricardo Reis, em terceira pessoa, a preencher as lacunas deixadas pelo rastro daquele que não pode valer sequer à Lídia. Não por outro motivo é $O$ ano da morte de Ricardo Reis. Ao contrário, Graciliano Ramos permanece atormentado, "Não sou um rato. Não quero ser um rato" (SANTIAGO, 1994, p. 18). Percorrem-lhe diversas intenções: escrever um diário, estabelecer-se no Rio de Janeiro com Heloísa, voltar a trabalhar após o trauma do cárcere. Daí, em Ramos, a extensão do tempo: a memória do cárcere; a atenção ao presente, "Encontrei um par de óculos semelhantes aos usados pelos curiosos míopes. Coloquei-os" (SANTIAGO, p. 51); e a expectativa, incerta, quanto ao futuro que se faz pela escrita do diário, pela elaboração da narrativa acerca da vida de Cláudio Manuel da Costa. 
Permanece a intenção. Decorre disso a importância da voz narrativa em primeira pessoa quando Em liberdade.

1935, 1936 e 1937. Desdobrados os tempos, teríamos mais de um século em apenas três anos. E esses são apenas três anos do breve século XX. Passamse os anos, alteram-se os espaços, umas personagens morrem, outras estão livres pela verdade da ficção. Múltiplo, o tempo vivido das narrativas humanas, o tempo do romance, engendra, pela revisão da história, os anos de 1789, 1936 e 1975. É a ênfase sobre o presente das experiências incertas de Graciliano Ramos e Ricardo Reis, característica ímpar dos romances Em liberdade e $O$ ano da morte de Ricardo Reis. "Não sinto o meu corpo. Não quero senti-lo por enquanto. Só permito, a mim, existir, hoje, enquanto consistência de palavras" (SANTIAGO, p. 21). Resiste, portanto, o instante da palavra literária onde acaba o mar e começa a terra.

\section{Referências bibliográficas}

ADORNO, Theodor. Primas: la crítica de la cultura y la sociedad. Barcelona: Ariel, 1962.

ARISTÓTELES. Arte poética. In: ARISTÓTELES. HORÁCIO. LONGINO. A poética clássica. São Paulo: Cultrix, 1997.

BAKHTIN, Mikhail. Epos e romance (Sobre a metodologia do estudo do romance). In: Questões de Literatura e de Estética (A Teoria do Romance). São Paulo:

Editora Hucitec, 1990.

BOSI, Alfredo. O tempo e os tempos. In: NOVAES, Adauto (Org.). Tempo e história. São Paulo: Companhia das Letras, 1992.

CANDIDO, Antonio. Literatura comparada. In: . Recortes. São Paulo:

Companhia das Letras, 1993.

CHARTIER. À beira da falésia: a história entre incertezas e inquietude. Porto Alegre: Ed. UFRGS, 2002.

GINZBURG, Carlo. Olhos de madeira: nove reflexões sobre a distância. São Paulo: Companhia das Letras, 2002. 
HUTCHEON, Linda. Poética do pós-modernismo: história, teoria e ficção. Rio de Janeiro: Imago, 1991.

LUKÁCS, Georg. Nota sobre o romance. In: NETTO, José Paulo (Org.). Sociologia. São Paulo: Editora Ática, 1992.

NUNES, Benedito. Narrativa histórica e narrativa ficcional. In: RIEDEL, Dirce Cortes (Org.). Narrativa, ficção e história. Rio de Janeiro: Imago, 1988.

PERRONE-MOISÉS, Leyla. Literatura comparada, intertexto e antropofagia. In: Flores da escrivaninha: ensaios. São Paulo: Companhia das Letras, 1990.

PESAVENTO, Sandra Jatahy. História e literatura: uma velha-nova história. In: COSTA, Cléria Botelho da; MACHADO, Maria Clara (Orgs.). História \& literatura: identidades e fronteiras. Uberlândia: Ed. UFU, 2006.

REIS, Ricardo. Odes de Ricardo Reis. In: PESSOA, Fernando. Obra poética. Porto Alegre: L\&PM, 2006.

RICOEUR, Paul. Tempo e narrativa. Tomo III. Campinas: Papirus, 1997.

SANTIAGO, Silviano. Em liberdade. Rio de Janeiro: Rocco, 1994.

SANTO AGOSTINHO. Confissões. São Paulo: Nova Cultural, 1996.

SARAMAGO, José. O ano da morte de Ricardo Reis. São Paulo: Companhia das Letras, 1988.

SHARPE, JIM. A história vista de baixo. In: BURKE, Peter. A escrita da história: novas perspectivas. São Paulo: Ed. UNESP, 1992. 